\title{
The Effectiveness Combination of Blended Learning and Flipped Classroom with Edmodo as a Digital Media Innovation for Learning From Home
}

\author{
Ramen Antonov Purba \\ ${ }^{1}$ Program Studi Manajemen Informatika, Politeknik Unggul LP3M, Indonesia \\ e-mail: ramenantonovpurba@gmail.com
}

\section{A R T I C L E I N F O}

Article history:

Received June 29, 2021

Revised June 30, 2021

Accepted July 28, 2021

Available online August 25, 2021

\section{Kata Kunci:}

Blended learning, flipped

classroom, edmodo, belajar dari rumah

Keywords:

Blended learning, Flipped classroom, Edmodo, Learning from home

DOI:

http://dx.doi.org/10.23887/jet.v 5i3.36210

\section{A B S T R A C T}

Covid-19 causes transformation. Educational institutions prepare teaching media that can be accessed online. Such as WhatsApp, Instagram, google meet, google classroom, and zoom. The media is not yet the right solution. This study aims to analyze the effectiveness of the blended learning model using the flipped classroom method with Edmodo. Quasi research and experimentation. Data analysis with the descriptive pattern. The technique of collecting data is by direct observation, filling out questionnaires, and carrying out tests. Analyzing information is carrying out initial knowledge testing, hypothesis testing, and analyzing learning activities. Through t-test, normality, homogeneity, and comparative to see the effectiveness of the combination of blended learning and flipped classroom with Edmodo. The research subjects were 32 students. The result is that the blended learning model using the flipped classroom method with Edmodo is effective as a medium for learning the context of learning from home. There are differences in the value and quality of individuals in learning. Value using WhatsApp, Instagram, google meet, google classroom, and Zoom 63.89. Using a combination of blended learning and flipped classroom with Edmodo 80.56. With the category of learning activities at the level of $92.1 \%$. The blended learning model with the flipped classroom method with Edmodo is effectively used. There is an increase in learning activities that have a positive impact on the value and quality of individual learning activities. The combination of the three is a new digital media innovation for learning.

This is an open access article under the CC BY-SA license. Copyright (C) 2021 by Author. Published by Universitas Pendidikan Ganesha.

\begin{abstract}
\begin{tabular}{l} 
A B S T R A K \\
\hline Covid-19 mengakibatkan transformasi. Institusi pendidikan mempersiapkan media \\
ajar yang dapat diakses secara online. Seperti WhatsApp, Instagram, google meet, \\
google classroom, dan zoom. Media tersebut belum menjadi solusi tepat. Tujuan \\
penelitian ini yaitu menganalisis efektivitas model blended learning metode flipped \\
classroom dengan edmodo. Penelitian mempergunakan quasi experimental. Analisa
\end{tabular}
\begin{tabular}{l} 
A B S T R A K \\
\hline Covid-19 mengakibatkan transformasi. Institusi pendidikan mempersiapkan media \\
ajar yang dapat diakses secara online. Seperti WhatsApp, Instagram, google meet, \\
google classroom, dan zoom. Media tersebut belum menjadi solusi tepat. Tujuan \\
penelitian ini yaitu menganalisis efektivitas model blended learning metode flipped \\
classroom dengan edmodo. Penelitian mempergunakan quasi experimental. Analisa
\end{tabular} \begin{tabular}{l} 
A B S T R A K \\
\hline Covid-19 mengakibatkan transformasi. Institusi pendidikan mempersiapkan media \\
ajar yang dapat diakses secara online. Seperti WhatsApp, Instagram, google meet, \\
google classroom, dan zoom. Media tersebut belum menjadi solusi tepat. Tujuan \\
penelitian ini yaitu menganalisis efektivitas model blended learning metode flipped \\
classroom dengan edmodo. Penelitian mempergunakan quasi experimental. Analisa
\end{tabular} \begin{tabular}{l} 
A B S T R A K \\
\hline Covid-19 mengakibatkan transformasi. Institusi pendidikan mempersiapkan media \\
ajar yang dapat diakses secara online. Seperti WhatsApp, Instagram, google meet, \\
google classroom, dan zoom. Media tersebut belum menjadi solusi tepat. Tujuan \\
penelitian ini yaitu menganalisis efektivitas model blended learning metode flipped \\
classroom dengan edmodo. Penelitian mempergunakan quasi experimental. Analisa
\end{tabular} data dengan pola deskriptif. Teknik mengumpulkan data dengan pengamatan langsung, pengisian lembar kuesioner, serta pelaksanaan uji. Teknik menganalisis data melaksanakan uji pengetahuan awal, uji hipotesis, serta menganalisis aktivitas efektivitas kombinasi blended learning dan flipped classroom dengan edmodo. Subjek penelitian 32 mahasiswa. Hasilnya Model blended learning metode flipped konteks belajar dari rumah. Terdapat perbedaan nilai serta kualitas individu dalam pembelajaran. Nilai menggunakan WhatsApp, Instagram, google meet, google classroom, dan Zoom 63,89. Menggunakan kombinasi blended learning dan flipped dipergunakan. Terjadi peningkatan dari segi aktivitas pembelajaran yang berdampak positif terhadap nilai dan mutu aktivitas belajar secara individual. Kombinasi ketiganya merupakan inovasi media digital baru pembelajaran. classroom dengan edmodo 80,56. Dengan kategori aktivitas belajar di level 92,1\%.
\end{abstract}

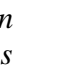


Initial observations, learning is still centred on the lecturer. Lecturers teach monotonously and give assignments. Using media ranging from WhatsApp, Instagram, google meet, google classroom, and some use Zoom. WhatsApp, Instagram, Google Meet, Google Classroom, and Zoom had weaknesses in learning activities during the Covid-19 period (Hamid et al., 2021; Qazi et al., 2021; Simamora, 2020). Low student grades. Student independence in learning activities is not as expected. Students tend to wait for instructions, and there is no initiative to find solutions or alternatives to complete assignments (Bradley, 2020; Syauqi et al., 2020). Information System Analysis and Design, which is an observation course, is an important subject. It must be mastered if we want to be a programmer. Do not choose the wrong learning media. Other media must be more interactive and more complete to accommodate the implementation of learning from home (Ferri et al., 2020; Mohr \& Shelton, 2017).

WhatsApp, Instagram, Google Meet, Google Classroom, and Zoom are ideally able to bridge learning activities between lecturers and students. It did not live up to expectations. The creativity and innovation of lecturers and students did not develop. WhatsApp, Instagram, google meet, google classroom, and Zoom have not been the right solutions for learning activities from home (Mpungose, 2021; Ramkissoon et al., 2020; Simamora, 2020; Yulando et al., 2019). Good learning, interactive learning, where lecturers and students interact and communicate well. Appropriate learning models and methods must be sought. Inappropriate learning tools must be abandoned, replaced with new models and methods (Angela, 2014; Hermawan et al., 2018; Ramkissoon et al., 2020). Even though the new models and methods are not all parties will be able to use them because there are factors of age, mastery of technology, and the level of ease and difficulty of using the technology. However, whatever the story, there must be a change from the old to the new that is felt more effective and efficient and able to bring about change (Balan et al., 2019; Tere et al., 2020; Van Woezik et al., 2019).

Blended Learning learning model with a context in the network. Blended learning has the context of a combination of many media in one container. There is room for discussion and collecting assignments virtually (Bervell \& Arkorful, 2020; Wu et al., 2019; Yustina et al., 2020). Blended learning is an ideal learning concept in unusual conditions. Blended learning allows learning media to be accessed from anywhere and anytime. It can be via cell phones (Arrosagaray et al., 2019; Mulyanto et al., 2020). Flipped Classroom is innovative, communicative, and dynamic or flexible. The hallmark of the Flipped Classroom model; 1) Dynamic. Learning is independent of time and location. Learning can be done anytime and anywhere; 2) Student Center. Learning does not only focus on lecturers but focuses on students. Students are allowed to improvise; 3) Material Adjustment. Material can be customized (Tse et al., 2019; Van Alten et al., 2019). How so that students can be challenged in learning something; 4) Interactive. Learning is more interesting because the existing content has been adapted to the needs. Flipped Classroom, when combined with technology, will make learning activities independent, communicative, and dynamic. Flipped Classroom allows students to study independently and dynamically at home, like when studying face-to-face in class. Flipped Classroom can be chosen as a timelimited learning solution by imposing responsibility on students to access learning media from home (Elfeky \& Masadeh, 2020; Lin et al., 2021). Bloom Anderson's taxonomy, associated with Flipped Classroom, will further enhance student independence (Leatherman \& Cleveland, 2020; Van Alten et al., 2019).

Flipped Classroom allows students to focus on activities that enhance higher-order thinking skills. It is based on the fact that students have different independence in learning activities. The media will not be able to work to increase student response. Still, there must be lecturer interaction to do it (Indah Septiani et al., 2020; Rubini et al., 2018). Edmodo is an educational technology that can be accessed and developed for free. Edmodo is a 21st-century innovation application where lecturers, students, and even parents can connect and communicate. Edmodo allows lecturers to integrate and manage learning easily, without risk, and free of charge. Lecturers can use the content on Edmodo in controlling and supervising their students. Therefore Edmodo can support Flipped Classroom-based learning (Balasubramanian et al., 2014; Sefriani et al., 2021). Initial observations, in this case analyzing the content of published articles, have not found publications explaining findings from an empirical point of view about the strengths and advantages of the combination of blended learning, flipped learning, and Edmodo as learning support, in this case in the Information Systems Design Analysis course. There has also been no publication of a combination of blended learning, flipped learning, and Edmodo for learning media during the Covid-19 pandemic (Elfeky \& Masadeh, 2020; Van Alten et al., 2019; Zainuddin \& Perera, 2019). Based on this explanation, research was compiled on the effectiveness of the combination of blended learning and flipped classrooms with Edmodo. It is hoped that the combination and combination of the three can become a new digital media innovation for learning from home to improve student learning abilities. Able to generate and develop creative thinking and students' ability to learn individually.

We will see the effectiveness of the combination of blended learning and flipped classroom with Edmodo as a digital media innovation for learning from home compared to using WhatsApp, Instagram, Google Meet, Google Classroom, and Zoom. The parameters, in this case, are accumulation (Assignments, Quis, Mid Test, and Final Test), creative thinking, and individual learning abilities. This research is necessary considering that the Covid-19 pandemic is not yet known when it will end. This research is also very urgent to do, 
considering that Indonesia is a country that is prone to abnormal situations. Not only covid-19 but also natural disasters that are also unpredictable when they occur. This study aims to analyze the effectiveness of the blended learning model with the flipped classroom method with Edmodo. This research will bring appropriate learning innovations.

\section{METHOD}

The type and design as a method of conducting this research are quasi-experimental with a nonequivalent control group design. It consists of two groups: WhatsApp, Instagram, Google Meet, Google Classroom, and Zoom and those using blended learning and flipped classrooms with Edmodo. For the type and design, visualize Figure 1 and Figure 2 :

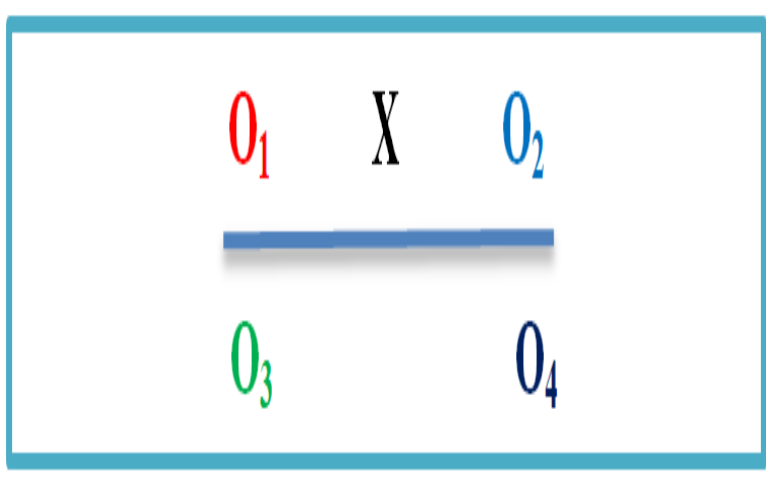

Figure 1. Research Method Visualization

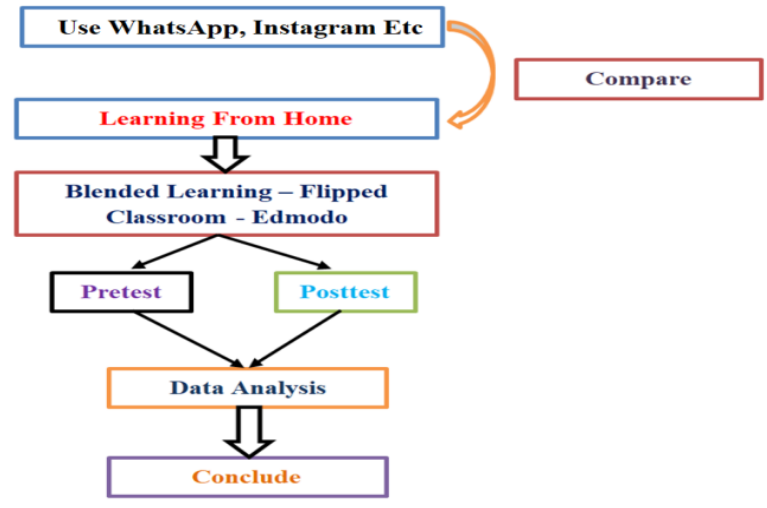

Figure 2. Research Stage Visualization

The research subjects were two classes of students of the Informatics Management study program at the Politeknik Unggul LP3M Medan. Consists of 40 students. Only 32 students are committed. Data analysis with descriptive pattern refers to five categories from the lowest value to the highest value. The concluded hypothesis refers to the gain value with the classification not high, slightly high, and high. The research variable is one independent variable with two categories and two dependent variables.

Data collection methods and instruments were carried out by direct observation, filling out questionnaire sheets, and carrying out tests. Utilization of instrument documents in observation sheets by marking what is carried out in learning activities. Filling out the questionnaire sheet is a way of collecting data by submitting a document containing a question sentence. The composition of the instrument document is in the form of a questionnaire assessing the quality of learning facilities as well as a questionnaire to validate the instrument document points for taking a test and non-test form data. The following instrument document is a questionnaire to assess students' creative thinking and ability to study individually (Anggito \& Setiawan, 2018). In the following, the instrument grid is presented, which is an illustration of the questionnaire sheet, which is visualized in the Table 1.

Table 1. Instrument Grid Overview of the Questionnaire Sheet

\begin{tabular}{ccccc}
\hline No. & Component & Parameter & Order of Points & Point Composition \\
\hline 1. & Mindset & Course Work & 1,5 & 6 \\
& & Confidence & $2,4,8,13$ & 8 \\
2. & Activity Control & Self Control & $3,6,14,16$ & 4 \\
& & Improvisation & $15,9,7,11$ & \\
3. & Self Mastery & Wisdom & 10,17 & 12,18 \\
& & Initiative & & $\mathbf{1 8}$ \\
\hline
\end{tabular}

The analytical method to analyze the data is by carrying out a student's initial knowledge test, carrying out hypothesis testing, and analyzing the progress of learning activities. It is carried out through t-test, normality test, homogeneity test, and comparative test to see the effectiveness of the combination of blended learning and flipped classroom with Edmodo as a digital media innovation for learning from home. 


\section{RESULT AND DISCUSSION}

Pre-test between students who study with blended learning with the flipped classroom method with Edmodo and those who use WhatsApp, Instagram, google meet, google classroom and zoom. Implemented using t-test. The test results were that students who learned to use WhatsApp, Instagram, google meet, google classroom, and zoom was found to have a sign (p-value) at 0.109 , where this number has a value greater than 0.05. Students who study with blended learning with the flipped classroom method with Edmodo were found to have a sign ( $p$-value) of 0.443 , where this number also has a value that has a weight greater than 0.05 . The data are classified in the form of usual categories. Both groups obtained scores in the normal category.

Next is the normality test. Students who learn to use WhatsApp, Instagram, google meet, google classroom, and zoom are found to have a sign (p-value) at 0.130 , where this number has a value greater than 0.05. Students who study with blended learning with the flipped classroom method with Edmodo were found to have a sign (p-value) of 0.676 , where this number also has a value that has a weight greater than 0.05 . The data are classified in the form of usual categories. Both groups received numbers in the normal category. It was concluded that students who studied with blended learning with the flipped classroom method with Edmodo and students who studied with WhatsApp, Instagram, Google Meet, Google Classroom, and Zoom could study individually in the same normal category. After that, the uniformity test (Test F). To see the level or extent of uniformity between students who use the Flipped Classroom Blended Learning Model with Edmodo and those who use WhatsApp, Instagram, Google Meet, Google Classroom, and Zoom. It was found that the F test results at 0.153 were more significant than 0.05 . The definition of the result is that there is uniformity in the two compositions originating from the same group. Next, the number 0.465 is found, which number is also more significant than the number 0.05 , so it can be drawn accurately, as described previously, that the two are also the same.

When it is found that the uniformity of distribution is not problematic (regular), a test is carried out to see the difference with a statistical pattern of t-test parameters on two parts of the sample whose positions are free. The number 0.082 is found; the number is greater than the number 0.05. Shows if Ho is accepted and Ha is rejected. Nothing different was found. In line with the finding of the number 0.357 , the number of numbers found also has a value greater than the number 0.05 . Precisely the same as the previous explanation, Ho is accepted, and $\mathrm{Ha}$ is rejected. There was no difference between the groups using the Blended Learning Model with the Flipped Classroom Method and Edmodo and WhatsApp, Instagram, Google Meet, Google Classroom, and Zoom. The next test is to get: 1) Are there different results in the scores obtained by students using the Blended Learning Model Flipped Classroom Method with Edmodo and using WhatsApp, Instagram, Google Meet, Google Classroom, and Zoom; 2) Are there different results in the quality of individual learning who use the Flipped Classroom Blended Learning Model with Edmodo and those who use WhatsApp, Instagram, google meet, google classroom, and Zoom. After completing the test to get the results of the qualification scores obtained by students who study using the Blended Learning Model, the Flipped Classroom Method with Edmodo and those who use WhatsApp, Instagram, Google Meet, Google Classroom, and Zoom with a pre and post-test pattern, the next step is also carried out a test to obtain the quality level of individual learning, students who study using the Blended Learning Model Flipped Classroom Method with Edmodo and those who use WhatsApp, Instagram, Google Meet, Google Classroom, and Zoom. Next is the accumulation of the overall hypothesis test for the $n$-gain. The results obtained will be used as a parameter to increase the value obtained by students and increase individual learning abilities.

Hypothesis testing requires several stages of testing, which is an initial requirement in the analysis, which is called an estimated test. This testing, namely the normality test and uniformity test. The normality test stage aims to obtain information on whether the distribution of the data obtained is almost equal to or by the distribution rules. For the results of the skewness and kurtosis normality test, it was found in the minus 2 to favourable two positions. It means that the distribution of data has a routine nature. Then based on the acquisition of basic numbers before accumulation in the WhatsApp, Instagram, Google Meet, Google Classroom, and Zoom groups, it was found that the acquisition of a sig number at 0.572 was categorized as having a value greater than 0.05. Likewise, it was found in the Blended Learning Model group with the Flipped Classroom Method with Edmodo, where it was found that the sig at 0.833 was categorized as having a value greater than 0.05 . Thus, it is precisely the same as the first explanation, that the data distribution has an utterly normal nature.

Next is the normality test for the $\mathrm{n}$-gain to see the quality of individual learning. There are still comparisons between the learning group and those using the Blended Learning Model, the Flipped Classroom Method with Edmodo, and WhatsApp, Instagram, Google Meet, Google Classroom, and Zoom. Skewness and kurtosis were found in the minus 2 to favourable two positions. It means that the data distribution has a routine nature. Then based on the acquisition of basic numbers before accumulation in the WhatsApp, Instagram, Google Meet, Google Classroom, and Zoom groups, it was found that the sig number was 0.293, which was categorized as having a value greater than 0.05. Likewise, it was found in the Blended Learning Model group 
with the Flipped Classroom Method with Edmodo, where a sig at 0.168 was found, which was categorized as having a value greater than 0.05 . Thus, it is the same as the first explanation, that the data distribution has an utterly normal nature.

The next step is to do a uniformity test. Implemented by t-test and f test. The goal is to see if the distribution is in a standard qualification. Then cumulatively, it will be found whether the composition is uniform or the opposite, that is, non-uniform. The composition of the n-gain values obtained by students with sig found the number of numbers 0.501 , whose total number was in a position more significant than the number 0.05. Thus can be classified as uniform composition. On the other hand, in the individual learning quality category, it was found that the $n$-gain was at 0.001 which the sum of the numbers had a value less than 0.05 . So the composition is said to be classified as non-uniform.

Next, evaluate learning activities, namely to see learning activities that use the Flipped Classroom Blended Learning Model with Edmodo and WhatsApp, Instagram, Google Meet, Google Classroom, and Zoom. The accumulated evaluation of learning activities is visualized in table 2. Following the visualization in table 2, it is found that the level of learning activity in groups that use WhatsApp, Instagram, Google Meet, Google Classroom, and Zoom is in the number of 82.8 to 87.5 in per cent units. For groups that use the Blended Learning Model, the Flipped Classroom Method with Edmodo, the numbers are 85.5 to 92.1 with per cent units. The figures illustrate that learning activities use the Blended Learning Model with the Flipped Classroom Method with Edmodo in its composition above learning activities using WhatsApp, Instagram, Google Meet, Google Classroom, and Zoom.

Table 2. Accumulated Learning Activity Evaluation

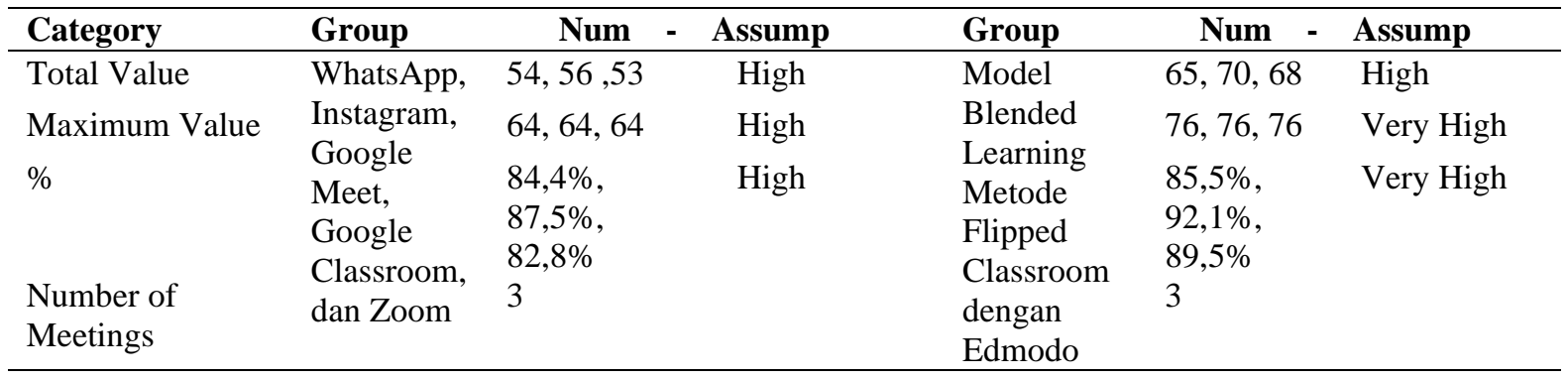

After going through a series of trials, it was found that the scores obtained by students using the Flipped Classroom Blended Learning Model with Edmodo and those using WhatsApp, Instagram, Google Meet, Google Classroom, and Zoom are visualized in Figure 3:

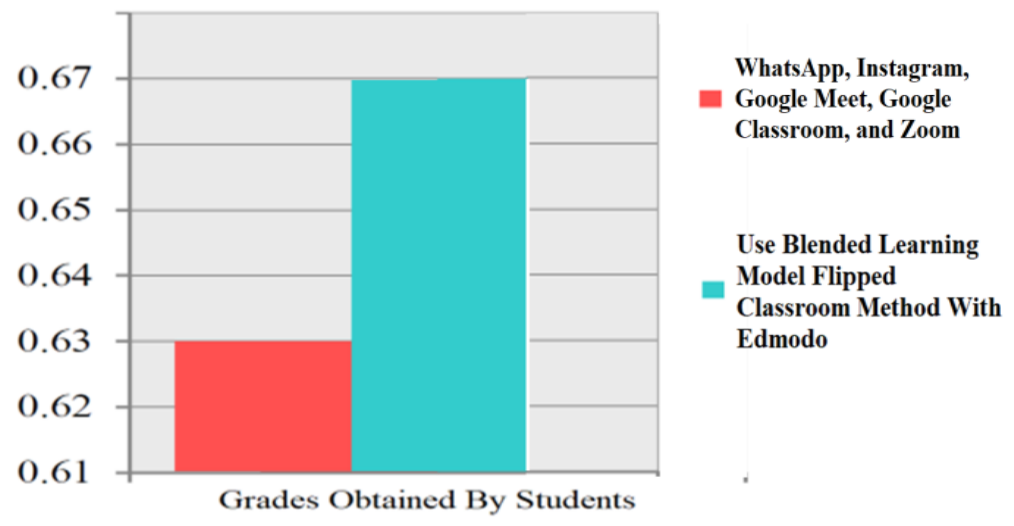

Figure 3. Visualization of Values Obtained by Students

Then the quality of individual learning using the Flipped Classroom Blended Learning Model with Edmodo and WhatsApp, Instagram, Google Meet, Google Classroom, and Zoom. For visualization in Figure 4: 


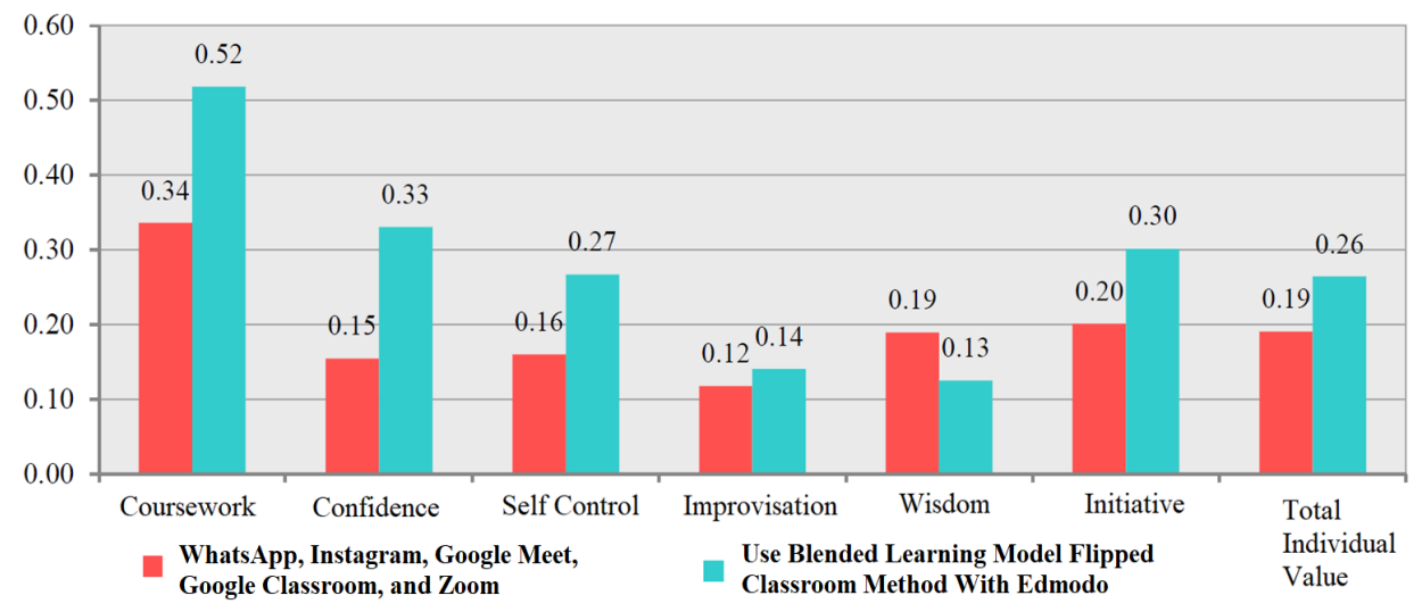

Figure 4. Visualization of Individual Learning Quality

The visualization is shown in Figure 3, and Figure 4 shows that the group that uses the blended learning model of the flipped classroom method with Edmodo has better individual values and quality in learning activities than groups that use WhatsApp, Instagram, Google Meet, Google Classroom, and Zoom. Then it was also found that the Blended Learning Model, the Flipped Classroom Method with Edmodo, was very effectively used to facilitate learning activities from home.

The effectiveness of learning activities using the Blended Learning model with the Flipped Classroom Method with Edmodo based on increasing the value of learning can be seen very clearly. There are differences in the improvement of learning outcomes in terms of increasing thinking skills and individual learning desires between students who apply the Flipped Classroom Blended Learning Model learning with Edmodo and those who use WhatsApp, Instagram, Google Meet, Google Classroom, and Zoom (Atmojo et al., 2020; Erdemir \& EKŞİ, 2019; Ramkissoon et al., 2020). The effectiveness of learning activities using the Blended Learning model Flipped Classroom Method with Edmodo based on increasing the quality of individuals in learning also looks very significant. The students who are often focused and adapt quickly will always be ready to learn and improve their learning quality (Foldnes, 2016; Qingqing, 2016; Van Alten et al., 2019). The quality of individual learning whose conditions are not similar results in students' potential to follow directions very quickly when the student is consistent to focus on learning. Especially students who learn to use WhatsApp, Instagram, Google Meet, Google Classroom, and Zoom are not supported with facilities. Learning uses the Blended Learning Model with the Flipped Classroom Method with Edmodo, where lecturers can regularly monitor and supervise student learning activities (Elfeky \& Masadeh, 2020; Erdemir \& EKŞİ, 2019; Leatherman \& Cleveland, 2020).

The instrument grid's existing components are the components consisting of Mindset, Activity Control, and Self-Mastery. The Course, Work Confidence, Self Control, Improvisation, Wisdom, and Initiative parameters, show that learning uses the Blended Learning Model Flipped Classroom Method with Edmodo is better than learning using WhatsApp, Instagram, Google Meet, Google Classroom, and Zoom. If students are given facilities that can make them monitor themselves in learning, students will be consistent and committed to being severe and simultaneous in learning activities (Anjelina \& Mawardi, 2021; Van Alten et al., 2019). It will focus on studying teaching materials to add new knowledge from existing references without being ordered by lecturers or parents. However, the Blended Learning Model with the Flipped Classroom Method with Edmodo still has problems in its implementation, impacting the research conducted (Qingqing, 2016; Van Alten et al., 2019; Wulandari et al., 2020) Blended Learning Model Flipped Classroom Method With Edmodo, an innovation of the digital learning model, requires a deeper introduction stage for students in learning activities, primarily based on the initiative aspect.

\section{CONCLUSION}

The students who learned to use the Blended Learning Model with the Flipped Classroom Method with Edmodo had better individual values and qualities than groups that used WhatsApp, Instagram, Google Meet, Google Classroom, and Zoom. Utilization of the Blended Learning Model The Flipped Classroom method with Edmodo has proven to support the quality and quality of learning in the context of learning from home. It is evident from the average development of creative thinking of students who learn to use the Blended Learning Model with the Flipped Classroom Method with Edmodo, which is much higher. 


\section{REFERENCES}

Angela, T. (2014). Challenges to Meaningful Learning in Social Studies - The Key Competences as an Opportunity to Students' Active Participation. Procedia - Social and Behavioral Sciences, 128, 192197. https://doi.org/10.1016/j.sbspro.2014.03.142.

Anggito, A., \& Setiawan, J. (2018). Metodologi Penelitian Kualitatif. CV Jejak (Jejak Publisher).

Anjelina, Y., \& Mawardi, M. (2021). Validity of Flipped Classroom Based on Guided Inquiry in Chemical Bonding Materials Using Edmodo. International Journal of Progressive Sciences and Technologies, 27(1), 29-34. https://doi.org/10.52155/ijpsat.v27.1.3023.

Arrosagaray, M., González-Peiteado, M., Pino-Juste, M., \& Rodríguez-López, B. (2019). A Comparative Study of Spanish Adult Students' Attitudes to ICT in Classroom, Blended and Distance Language Learning Modes. Computers and Education, 134(October 2018), 31-40. https://doi.org/10.1016/j.compedu.2019.01.016.

Atmojo, S. E., Muhtarom, T., \& Lukitoaji, B. D. (2020). The Level of Self-Regulated Learning and SelfAwareness in Science Learning in the Covid-19 Pandemic Era. Jurnal Pendidikan IPA Indonesia, 9(4), 512-520. https://doi.org/10.15294/jpii.v9i4.25544.

Balan, L., Yuen, T., \& Mehrtash, M. (2019). Problem-Based Learning Strategy for CAD Software Using FreeChoice and Open-Ended Group Projects. Procedia Manufacturing, 32, 339-347. https://doi.org/10.1016/j.promfg.2019.02.223.

Balasubramanian, K., Jaykumar, V., \& Fukey, L. N. (2014). A Study on "Student Preference towards the Use of Edmodo as a Learning Platform to Create Responsible Learning Environment. Procedia - Social and Behavioral Sciences, 144. https://doi.org/10.1016/j.sbspro.2014.07.311.

Bervell, B., \& Arkorful, V. (2020). LMS-Enabled Blended Learning Utilization in Distance Tertiary Education: Establishing the Relationships among Facilitating Conditions, Voluntariness of Use and Use Behaviour. International Journal of Educational Technology in Higher Education, 17(1), 6. https://doi.org/10.1186/s41239-020-0183-9.

Bradley, V. M. (2020). Learning Management System (LMS) Use with Online Instruction. International Journal of Technology in Education, 4(1), 68. https://doi.org/10.46328/ijte.36.

Durnali, M. (2020). The Effect of Self-Directed Learning on the Relationship Between Self-Leadership and Online Learning among University Students in Turkey. Tuning Journal for Higher Education, 8(1), 129-165. https://doi.org/10.18543/tjhe-8(1)-2020pp129-165 Received.

Elfeky, A. I. M., \& Masadeh, T. S. Y. (2020). Advance Organizers in Flipped Classroom Via E-Learning Management System and the Promotion of Integrated Science Process Skills. Thinking Skills and Creativity, 35. https://doi.org/10.1016/j.tsc.2019.100622.

Erdemir, N., \& EKŞİ, G. Y. (2019). The Perceptions of Student Teachers about Using an Online Learning Environment 'Edmodo' in a 'Flipped Classroom.' SDU International Journal of Educational Studies, 6(2), 174-186. https://doi.org/10.33710/sduijes.638795.

Ferri, F., Grifoni, P., \& Guzzo, T. (2020). Online Learning and Emergency Remote Teaching: Opportunities and Challenges in Emergency Situations. Societies, 10(4), 86. https://doi.org/10.3390/soc10040086.

Foldnes, N. (2016). The Flipped Classroom and Cooperative Learning: Evidence from a Randomised Experiment. SAGE Journal, 17(1). https://doi.org/10.1177\%2F1469787415616726.

Giovannella, C. (2021). Effect Induced by the Covid-19 Pandemic on Students' Perception about Technologies and Distance Learning. Ludic, Co-Design and Tools Supporting Smart Learning Ecosystems and Smart Education (pp. 105-116). Springer.

Hamid, S. N. M., Lee, T. T., Taha, H., Rahim, N. A., \& Sharif, A. M. (2021). E-Content Module for Chemistry Massive Open Online Course (Mooc): Development and Students' Perceptions. Journal of Technology and Science Education, 11(1), 67-92. https://doi.org/10.3926/jotse.1074.

Hermawan, Putro, K. H., \& Sugini. (2018). The Effectiveness of Course Review Horay Method on Social Sciences Learning Achievement of Visually Impaired Students. Journal of Icsar, 2(2). https://doi.org/10.17977/um005v2i22018p153.

Indah Septiani, A. nisa N. S., Septiani, I., Rejekiningsih, T., Triyanto, \& Rusnaini. (2020). Development of Interactive Multimedia Learning Courseware to Strengthen Students' Character. European Journal of Educational Research, 9(3), 1267-1279. https://doi.org/10.12973/eu-jer.9.3.1267.

Leatherman, J. L., \& Cleveland, L. M. (2020). Student Exam Performance in Flipped Classroom Sections is Similar to that in Active Learning Sections, and Satisfaction with the Flipped Classroom Hinges on Attitudes toward Learning from Videos. Journal of Biological Education, 54(3), 328-344. https://doi.org/10.1080/00219266.2019.1575266.

Lin, Y.-N., Hsia, L.-H., \& Hwang, G.-J. (2021). Promoting Pre-Class Guidance and In-Class Reflection: A SQIRC-Based Mobile Flipped Learning Approach to Promoting Students' Billiards Skills, Strategies, Motivation, and Self-Efficacy. Computers \& Education, 160. https://doi.org/10.1016/j.compedu.2020.104035. 
Mohr, S. C., \& Shelton, K. (2017). Best Practices Framework for Online Faculty Professional Development: A Delphi Study. Online Learning Journal, 21(4). https://doi.org/10.24059/olj.v21i4.1273.

Mpungose, C. B. (2021). Lecturers' Reflections on Use of Zoom Video Conferencing Technology for ELearning at a South African University in the Context of Corona Virus. African Identities. https://doi.org/10.1080/14725843.2021.1902268.

Mulyanto, B. S., Sadono, T., Koeswanti, H. D., Dasar, S., Wonodoyo, N., Tengah, J., Kristen, U., Wacana, S., \& Tengah, J. (2020). Evaluation of Critical Thinking Ability with Discovery Lerning Using Blended Learning Approach in Primary School. Journal of Educational Research and Evaluation, 9(2), 78-84. https://doi.org/10.15294/jere.v9i2.46135.

Qazi, A., Qazi, J., Naseer, K., Zeeshan, M., Qazi, S., Abayomi-alli, O., Ahmad, I. S., Darwich, M., Talpur, A., Hardaker, G., Naseem, U., Yang, S., \& Haruna, K. (2021). Adaption of Distance Learning to Continue the Academic Year Amid COVID-19 Lockdown. Journal Pre-Proofs (Children and Youth Services Review), 1-20. https://doi.org/10.1016/j.childyouth.2021.106038.

Qingqing, H. U. (2016). Research on Flipped Classroom Design and Implication Based on Edmodo Platform. 2016 Eighth International Conference on Measuring Technology and Mechatronics Automation (ICMTMA), 528-532. https://doi.org/10.1109/ICMTMA.2016.131.

Ramkissoon, P., Belle, L. J., \& Bhurosy, T. (2020). Perceptions and Experiences of Students on the Use of Interactive Online Learning Technologies in Mauritius. International Journal of Evaluation and Research in Education. https://doi.org/10.11591/ijere.v9i4.20692.

Rubini, B., Permanasari, A., \& Yuningsih, W. (2018). Learning Multimedia Based on Science Literacy on the Lightning Theme. Journal of Science Learning and Research, 4(2), 89-104. https://doi.org/10.30870/jppi.v4i2.3926.

Sefriani, R., Sepriana, R., Wijaya, I., \& Radyuli, P. (2021). Blended Learning with Edmodo: The Effectiveness of Statistical Learning during the Covid-19 Pandemic. International Journal of Evaluation and Research in Education, 10(1), 293-299. https://doi.org/10.11591/ijere.v10i1.20826.

Simamora, R. M. (2020). The Challenges of Online Learning during the COVID-19 Pandemic: An Essay Analysis of Performing Arts Education Students. Studies in Learning and Teaching, 1(2), 86-103. https://doi.org/10.46627/silet.v1i2.38.

Solehana, L., Asrori, A., \& Usman, A. (2019). The Development of E-Learning Teaching Material Based on Edmodo on Basic Competencies of National Integration at Class X of Senior High School. Journal Of Education, Teaching And Learning, 4(2). https://doi.org/10.26737/jetl.v4i2.1914.

Syauqi, K., Munadi, S., \& Triyono, M. B. (2020). Students' Perceptions Toward Vocational Education on Online Learning During the Covid-19 Pandemic. International Journal of Evaluation and Research in Education (IJERE), 9(4), 881. https://doi.org/10.11591/ijere.v9i4.20766.

Tere, T., Bayu Seta, H., Nizar Hidayanto, A., \& Abidin, Z. (2020). Variables Affecting E-Learning Services Quality in Indonesian Higher Education: Students' Perspectives. Journal of Information Technology Education: Research, 19, 259-286. https://doi.org/10.28945/4489.

Tse, W. S., Choi, L. Y. A., \& Tang, W. S. (2019). Effects of Video-Based Flipped Class Instruction on Subject Reading Motivation. British Journal of Educational Technology, 50(1), 385-398. https://doi.org/10.1111/bjet.12569.

Van Alten, D. C. D., Phielix, C., Janssen, J., \& Kester, L. (2019). Effects of Flipping the Classroom on Learning Outcomes and Satisfaction: A Meta-Analysis. Educational Research Review, 28(June), 1-18. https://doi.org/10.1016/j.edurev.2019.05.003.

Van Woezik, T., Reuzel, R., Koksma, J., \& Serpa, S. (2019). Exploring Open Space: A Self-Directed Learning Approach for Higher Education. Cogent Education, 6(1), 1-22. https://doi.org/10.1080/2331186X.2019.1615766.

Wu, W. H., Kao, H. Y., Wu, S. H., \& Wei, C. W. (2019). Development and Evaluation of Affective Domain Using Student's Feedback In Entrepreneurial Massive Open Online Courses. Frontiers in Psychology, 10(MAY). https://doi.org/10.3389/fpsyg.2019.01109.

Wulandari, I. G. A. A. M., Sudatha, I. G. W., \& Simamora, A. H. (2020). Pengembangan Pembelajaran Blended pada Mata Kuliah Ahara Yoga Semester II di IHDN Denpasar. Jurnal Edutech Undiksha, 8(1), 1. https://doi.org/10.23887/jeu.v8i1.26459.

Yulando, S., Sutopo, S., \& Franklin Chi, T. (2019). Electronic Module Design and Development: An Interactive Learning. American Journal of Educational Research, 7(10), 694-698. https://doi.org/10.12691/education-7-10-4.

Yulia. (2020). Online Learning to Prevent the Spread of Pandemic Corona Virus in Indonesia. ETERNAL (English Teaching Journal), 11(1). https://doi.org/10.26877/eternal.v11i1.6068.

Yustina, Syafii, W., \& Vebrianto, R. (2020). The Effects of Blended Learning and Project-Based Learning on Pre-Service Biology Teachers' Creative Thinking Skills through Online Learning in the COVID-19 Pandemic. Jurnal Pendidikan IPA Indonesia, 9(3), 408-420. https://doi.org/10.15294/jpii.v9i3.24706. 
Zainuddin, Z., \& Perera, C. J. (2019). Exploring Students' Competence, Autonomy and Relatedness in the Flipped Classroom Pedagogical Model. Journal of Further and Higher Education, 43(1), 115-126. https://doi.org/10.1080/0309877X.2017.1356916. 